\title{
Peace for Atoms. US Non-Proliferation Policy and the Romanian Role in the Sino-American Rapprochement, 1969-1971
}

\author{
Eliza Gheorghe
}

\begin{abstract}
By 1970, the United States had undergone a remarkable volte-face on dealing with People's Republic of China as a nuclear weapon state, from outspoken opposition to political recognition. Aware of the importance of co-opting Beijing in the emerging multipolar order, President Richard Nixon sought any possible opening to the Chinese leadership. One secret backchannel passed through Bucharest, whom Washington rewarded with sensitive atomic assistance for its good offices. If in the mid-1960s dealing with China was regarded as detrimental to the cause of nonproliferation, by the early 1970s, the United States relaxed its nuclear exports policy towards useful adversaries, such as Romania, all in pursuit of geopolitical interests.
\end{abstract}

\section{KEYWORDS}

Nuclear proliferation; nuclear trade; Sino-American rapprochement

\section{Introduction}

Among the many issues discussed in the introduction of this special issue on The historiography on the 1970s and the making of the nuclear order, the role of the United States in the governance of the international non-proliferation regime stands out as an important focal point of academic inquiry. The editors ask two important and related questions pertaining to the long 1970s: what could the United States do to stem nuclear proliferation in an age of technological diffusion and unabated contestation from the global South? In the first few decades of the nuclear age, the answer seems to be: not much. Proliferation appeared inevitable and unstoppable. Over 70\% of all proliferators emerged between 1945 and 1968. This finding leads to the second question: would it not be better for Washington to try to steer the spread of nuclear weapons instead of wasting important resources in the attempt to stop it altogether?

Managing the nuclear order, as Or Rabinowitz has shown, involves cutting deals with allies, allowing them to pursue their nuclear ambitions in exchange for promises of restraint. ${ }^{1}$ Such compromises could not be reached with hostile states like China, who, rather than vowing to forswear atomic bombs, welcomed nuclear war. ${ }^{2}$ Containing proliferation and mitigating the effects of nuclear weapons ending up in the hands of bellicose leaders like Mao Zedong involved a wide variety of policies, from signing the Limited Test Ban Treaty to extending the nuclear umbrella over potential targets like Taiwan, and from threatening a preemptive attack to sanctions, political isolation and diplomatic non- 
recognition. ${ }^{3}$ If in 1964, the Gilpatric Committee viewed China's admission to the UN as a step in the wrong direction from a non-proliferation perspective, by 1968, the Johnson administration acquiesced to having China included among the five 'legitimate' nuclear weapon states under the Treaty on the Non-Proliferation of Nuclear Weapons (NPT). ${ }^{4}$ Nixon took this policy one step further and embarked on the path to full political recognition.

At a time when the USA had secured over $70 \%$ of the nuclear market (see Figure 1), American policy-makers felt more confident about their ability to deal with the repercussions of recognizing the communist regime in Beijing. In the emerging multipolar setting of the late 1960s and early 1970s, co-opting China in the budding nuclear order appeared wiser than ignoring or, even worse, opposing it. ${ }^{5}$ The road to a rapprochement with Beijing was paved with hard decisions that occasionally involved nuclear proliferation. The story of the Romanian nuclear program and its connection to the US opening to China provide a unique insight into the trade-offs Washington had to make. It was not only allies that the USA was willing to cut deals with, but also useful adversaries that could provide certain benefits. Missing the opportunity to engage with China to curtail the nuclear ambitions of a medium-to-small power like Romania represented a cost US top decision-makers proved unwilling to incur.

Romania was one of the actors on the margins of the Cold War which knew how to capitalize on Nixon's eagerness to reach out to China. A quid pro quo arrangement emerged between Nicolae Ceaușescu, the General Secretary of the Romanian Communist Party (RCP), and the Nixon Administration: in exchange for mediating between Washington and Beijing, the Americans would provide Romania with sensitive nuclear assistance. ${ }^{6}$ The leadership in Bucharest sought to acquire a nuclear research reactor, together with highly enriched uranium (HEU) fuel supplies, and a heavy water plant. ${ }^{7}$

High-ranking members involved in the US-Romanian negotiations on atomic assistance suspected Ceausescu had adopted a nuclear hedging strategy, but continued

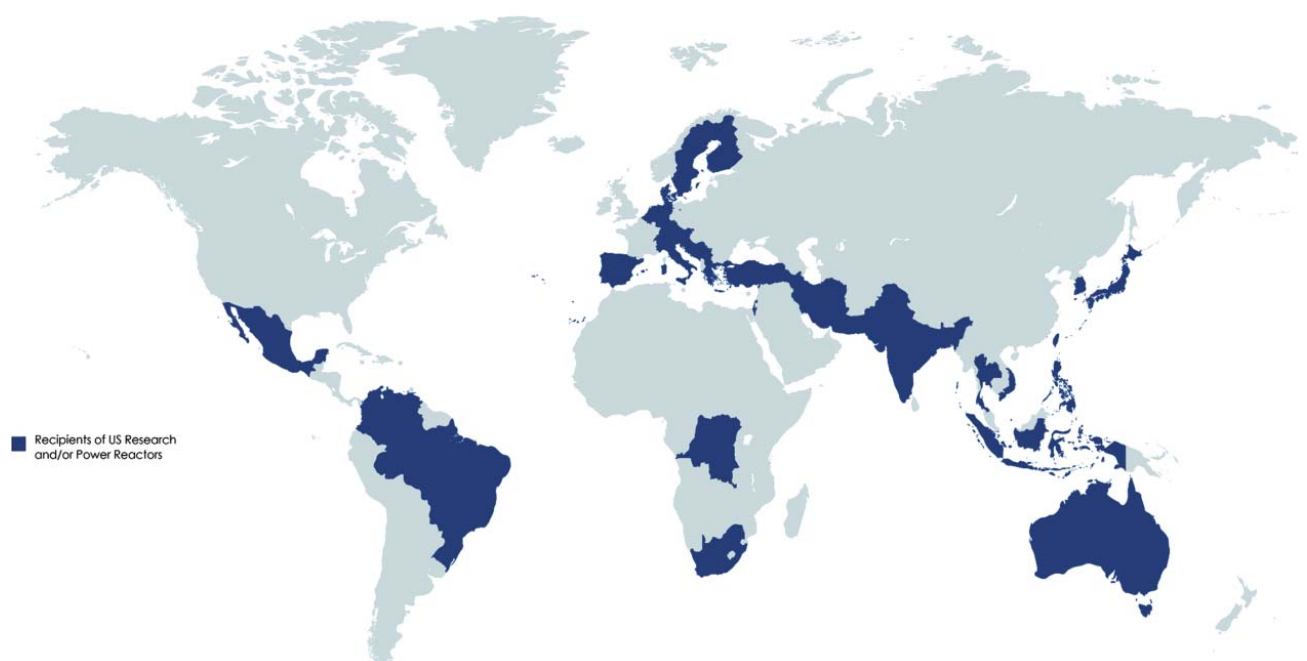

Figure 1. Recipients of US nuclear technology transfers (research and power reactors).

Source: Eliza Gheorghe, A History of Nuclear Trade (unpublished manuscript). 
to support the deal because of the geopolitical benefits Bucharest's help with the Sino-American rapprochement would bring. For the Nixon administration, stemming Romania's nuclear ambitions proved to be secondary to normalizing relations with Beijing. The lack of roll-back measures directed against Romania's nuclear program added to the pressures that prevented the US from establishing an effective international non-proliferation regime, especially since the deal was approved shortly after the NPT was ratified. If Washington's inhibition strategy later found it difficult to dissuade other countries, such as Yugoslavia, Egypt, Brazil or Argentina, from going down the nuclear road, it may have been because these countries took notice of US' lax attitude towards Ceaușescu, who, in the 1970s, became increasingly vocal about keeping the nuclear option in his pocket.

The Romanian communist leader established his credentials as a mediator as early as 1967, when Nixon visited Romania as a private citizen. In the 1960s, Bucharest's close ties with North Vietnam enabled it to serve as a backchannel between Washington and Hanoi. Thanks to this unorthodox barter, the Romanians and the Americans signed a Nuclear Cooperation Agreement which promised the delivery of nuclear technology. ${ }^{8}$ In the early 1970s, the leadership in Bucharest managed to repeat this feat, using its good offices between Washington and Beijing as leverage in its negotiations with Nixon and his National Security Adviser, Henry A. Kissinger. Once again, Ceaușescu capitalized on Washington's plans to end hostilities in Asia to gain access to nuclear technology, in what I call a 'Peace for Atoms' arrangement.

Romania's role in the Sino-American rapprochement has been analyzed before. ${ }^{9} \mathrm{How}$ ever, the existing scholarship misses the important role that nuclear technology played in Bucharest's efforts, and mistakenly assumes that the Romanian mediation did not achieve much. Thanks to recently released documents, this analysis can contribute towards a fuller narrative, and an interpretation of events which casts the Romanian initiative in a different light. Far from being a botched attempt at 'to-ing and fro-ing' between Washington and Beijing, Bucharest's diplomatic machinations paid off handsomely. The Romanian backchannel, because of its simultaneous connection with the Americans, the Soviets and the Chinese, made a valuable contribution to Nixon's opening to China, while also advancing the Romanian nuclear program. The reward for the frantic shuttle diplomacy that Romanian officials carried out for almost two years - a dual-core TRIGA (Training, Research, Isotopes, General Atomics) nuclear reactor - brought Ceaușescu's nuclear ambitions closer to fruition. The American-Romanian nuclear deal, which included the transfer of a significant quantity of HEU (enough for almost two nuclear bombs), became the first, and only such transaction between the US and a Warsaw Pact country. ${ }^{10}$

\section{Nixon in Bucharest}

The seeds of the Romanian involvement in the Sino-American rapprochement were planted before Nixon came to the White House, during his so-called 'wilderness years' (1962-1968) when he paid a visit to Bucharest as a private citizen. ${ }^{11}$ Nixon's interest in normalizing relations with Beijing indicated to Ceaușescu that the world was on the cusp of a tidal change in international relations. More important, Ceaușescu realized that Romania could greatly benefit from a Sino-American rapprochement, first and foremost in the nuclear arena. When Nixon asked Ceaușescu for advice on how to deal with China, the 
Romanian leader first tackled the issue of nuclear proliferation and unhindered access to atomic energy, and only then offered his views on how to mend fences with Beijing. ${ }^{12}$ When discussing the NPT, which the US and the USSR were fervently promoting, Ceaușescu highlighted both its discriminatory nature and the impossibility to stop countries from developing their own atomic infrastructures. ${ }^{13}$ Rather than trying to keep other states away from nuclear technology, Ceaușescu implied, the superpowers should provide assistance, which they were both doing under the Atoms for Peace and Peaceful Atom programs.

Bucharest's interest in atomic energy, however, was not confined only to peaceful uses; the Romanian leadership also wanted to keep the nuclear option open. Just a few days before Nixon's visit, the Romanian Prime Minister, Ion Gheorghe Maurer, told Leonid Brezhnev and Alexei Kosygin that the main impediment to the acquisition of a nuclear weapon was the lack of technological capabilities. 'If Romania could produce a nuclear bomb, it would probably do so. ${ }^{14}$ Ceaușescu's campaign to acquire American nuclear technology and materials should, therefore, be seen as part and parcel of broader strategy to acquire a 'standby' capability. ${ }^{15}$

Bucharest knew it had to perform a delicate balancing act: the Sino-Soviet split prompted Nixon's overture to Beijing, but it also placed Bucharest under considerable strain. For two years, the Romanians tried to keep a low profile so as not to get caught in the cross-fire between Moscow, Beijing and Washington. Tensions were running high, especially after the invasion of Czechoslovakia in August 1968 and the military clashes on Zhenbao Island in March 1969. The Romanians had to please not one but three actors: the intransigent Chinese, unwilling to make peace with either Washington or Moscow; the perplexed Soviets, embarrassed about having failed to restore unity to the international communist movement; the ambitious Americans, willing to dig into their deep pockets to get what they wanted. Serving as a mediator in these circumstances was no easy task, yet a glimmer of hope showed itself in May 1969. The Chinese now started to warm to the Romanians, especially since they felt increasingly isolated by the rest of the communist bloc. Qiao Guanhua, a Deputy Minister in the Chinese Ministry of Foreign Affairs, told Aurel Duma, the Romanian Ambassador to Beijing, that:

lately, the Soviets have been intensifying military drills along the border. [...] The Chinese government believes that these actions represent intimidation attempts ordered by the Soviet leadership, who believes solely that might is right and who imagines that it could intimidate peoples with the A-bomb. This is wrong; if Romania was not intimidated, how could China [ever] be intimidated? ${ }^{16}$

Faced with the prospects of large-scale military operations and Soviet diplomatic encirclement, the Chinese seemed to have moved an inch closer to rapprochement with the US. While Qiao Guanhua still lashed out at the US for supporting Taiwan, his statements revealed an important change in Beijing's approach to negotiating with the Americans: 'The Chinese government will assess the US position towards China by judging deeds not just words. ${ }^{17}$ Bucharest knew that Washington's interest in normalizing relations with China had to go beyond mere rhetoric; Nixon had to do something to prove to Mao that Washington meant business. The very idea that the Chinese were open to being persuaded with 'deeds' was a significant shift. 
Beijing had not yet decided to normalize relations with the US. However, it seemed that rumors in the Eastern bloc about Mao's rationale for stirring up tensions with Moscow became a self-fulfilling prophecy:

This [the attack] is some kind of an offer from China to America, a signal that there is no possibility for an understanding between China and the USSR. This is an offer extended to Nixon so he can take advantage of it all, especially all the more since Nixon has not yet decided what direction to take in his policy. ${ }^{18}$

Although these gossips might have overestimated Beijing's careful planning of events, the Chinese did appear to experience a significant shift in their foreign policy, especially with regards to the US.

So on 3 June the Romanians tested the waters and attempted their first mediation effort between China and the US. The Romanian Ambassador to Beijing informed Qiao Guanhua that a group of American senators wanted to pay an unofficial visit to China. ${ }^{19}$ He replied that 'we [the Chinese] are for peaceful coexistence with all countries, even with the United States, but we can't apply the principles of this policy if the US is hostile towards China.' ${ }^{20}$ The 'new' approach adopted by the US, according to Qiao Guanhua, was nothing but old wine in new bottles: 'Nixon's policy is still fundamentally reactionary, war-mongering, and aggressive towards China. ${ }^{21}$ For tensions between the US and China to subside, Washington had to pull out of Taiwan and the Taiwan Strait. ${ }^{22}$ Compared to the bellicosity and intransigence of previous years, Beijing's new position nevertheless signaled a shift towards 'constructive criticism'. Long gone were the days when Mao threatened the US with nuclear war, warning that the principle of Mutual Assured Destruction did not apply to China because of its demography. Now Beijing, despite its denunciation of US policies, mapped out the specific steps Washington had to take to make reconciliation possible.

This new thinking emerged from the state of seclusion Mao found himself in: 'We are now isolated. No one wants to make friends with us. ${ }^{23}$ Romania was among the few countries still standing by China, at least on some occasions. Beijing's keenness to maintain and improve ties with Bucharest was part of Mao's strategy to counter the Soviet political and diplomatic offensive in Asia and to redress China's isolation. Mao mandated four Chinese marshals (Chen Yi, Nie Rongzhen, Ye Jianying and Xu Xiangqian) to write a report on international relations. ${ }^{24}$ The four marshals' analysis, submitted on 11 July 1969, concluded that although Beijing should continue to oppose both the United States and the Soviet Union, war with the US was highly unlikely, while a quick Soviet 'war of aggression against China' was possible. ${ }^{25}$ Even if Beijing had not yet decided to pursue rapprochement with the US, the foundations for later developments were starting to take shape. Even before the four marshals finished the report, the Chinese Deputy Foreign Minister intimated to the Romanian Ambassador Beijing's thoughts about peaceful coexistence with the USA.

At his end, Nixon, now US President, adopted several measures meant to ease tensions with China, such as lifting travel and trade restrictions, but he failed to signal these changes to Beijing because he did not want to make his moves public. ${ }^{26}$ In early July, he tasked his foreign policy aides with writing NSSM 63 (the National Security Study Memorandum 63), which dealt with the implications of the Sino-Soviet rivalry. His National Security Adviser, Henry A. Kissinger, had already been briefed on 24 June 1969, about the positive effects a Sino-American rapprochement could have on US-USSR relations. ${ }^{27}$ By 
playing off Moscow and Beijing against one another, Washington could improve relations with both. It was in this context that in late spring 1969, the RCP leadership invited Nixon to visit Bucharest that summer.

Nixon accepted the invitation in early July 1969 and visited Bucharest a few weeks later, squeezing in a stopover in Bucharest during his return trip from the Southern Pacific, where he had witnessed the Apollo 11 splashdown. A decision on whether or not to loosen US export controls vis-à-vis Romania, including in the field of atomic energy, depended on a variety of factors, including Bucharest's position on international issues such as the Sino-Soviet confrontation. Since the trip had been planned on such short notice, the National Security Council (NSC) had little time to draft proposals and memoranda on how to improve relations with the Romanians. Therefore, Nixon and Kissinger would have to partly continue the policies adopted under Lyndon Johnson and partly improvise. Kissinger did underline, however, that the Romanians could be useful as conduits to Beijing. ${ }^{28}$

On 2 August 1969, Nixon arrived in Bucharest. It was a glorious day: the sun was shining against a clear blue sky, a gentle breeze made the scorching Bucharest air breathable. The RCP leadership knew the omens looked good as soon as the US President, to everyone's amusement, clumsily tried to pronounce a few words in Romanian. Hundreds of thousands of people lined the boulevards from the airport to downtown Bucharest to welcome the presidential motorcade and show their excitement for the first visit of a US president to Romania. ${ }^{29}$ Ceaușescu was beaming with pride: here he was, waving to the ecstatic crowds alongside Nixon, less than one year after the invasion of Czechoslovakia.

When the two leaders sat down for serious negotiations, Ceaussescu did not waste time with pleasantries. He cut straight to the chase, bringing up first and foremost the nuclear energy assistance issue: 'I attach great importance to cooperation in science and technology because this field has a decisive part to play in the development of a country,' he pointed out. ${ }^{30} \mathrm{He}$ then sought to reassure Nixon that Romania did not pose any risks as far as nuclear proliferation was concerned: '[With] regard to physics, we don't want nuclear weapons, but would wish to use nuclear energy for peaceful purposes.' He then took the whole issue apart, piece by piece. Economic assistance from the US to Romania, which included nuclear cooperation, was too low, he said. The US could take specific measures to address this problem. First, it could issue licenses to Romania to import equipment (including nuclear technology); second, it could relax barriers to trade with Romania, so that Bucharest could earn enough money from exports to pay for the imports of American technology. Those two related matters could be solved with a single 'magic bullet': granting Romania Most Favored Nation (MFN) status.

Nixon was forthcoming:

I want you to know I favor MFN treatment for Romania. Once the political problems of the Vietnam War are gone, we will move expeditiously on this. I, that is the President, can now, without Congressional action, change the status of Romania on direct sales in several areas. I will do that. I will ease export licensing to Romania and Export/Import Bank questions where I can act administratively. ${ }^{31}$

In return Nixon asked Ceaușescu for help with China: 'Frankly, if it serves your interest and the interest of your government, we would welcome you playing a mediating role between us and China. ${ }^{32}$ The conditions for this opening, according to Nixon, were ripe: 
We know of the Soviet Union's quarrel with China. That is one we will stay out of. Our policy is to have good relations with the Soviet Union and eventually when China changes its approach to other nations, we want to open communications channels with them to establish relations. One billion Chinese fenced in is a bomb about to explode. ${ }^{33}$

Ceaușescu accepted the offer, but made sure to cover his back:

As to our willingness to mediate between the US and China-the US has every possibility to talk directly with the Chinese without mediation-I will say we shall tell our opinion to the Chinese, and of your opinion of this problem. We shall act to establish relations on the basis of mutual understanding. ${ }^{34}$

Unfortunately, Ceaușescu did not have an opportunity to communicate with the Chinese leadership right after his meeting with Nixon. He relayed the gist of their conversation to Zhou Enlai through the Chinese ambassador, but he could not convey the most important parts of the conversation - Nixon's intention to normalize relations with Beijing - probably for fear of leaks. ${ }^{35}$ The opportunity to talk face-to-face with the Chinese kept slipping through the Romanians' fingers, as Mao declined Ceaușescu's invitation to attend the RCP Congress and to celebrate Romania's National Day in Bucharest, both of which took place in August 1969. The Chinese leadership explained that it wanted to avoid at all costs being in the same room with 'traitor cliques led by Soviet revisionists. ${ }^{36}$

\section{Ho Chi Minh's Funeral}

An opportunity finally showed itself on 7 September 1969, when Prime Minister Maurer and Paul Niculescu Mizil stopped over in Beijing, en route to Hanoi, to attend Ho Chi Minh's funeral. Meeting in the dead of night, probably to avoid the prying eyes of other diplomats, including the Soviets, Maurer and Niculescu Mizil gave Zhou Enlai an almost verbatim account of Ceaușescu's conversation with Nixon. Maurer began by emphasizing how much Nixon wanted to put past animosities between Washington and Beijing behind him: 'First and foremost, Nixon manifested, without any reservations, his desire to find a way to normalize relations with China. He said it loud and clear and he asked us, if possible, for a helping hand. ${ }^{37}$ To avoid creating the impression that the RCP wanted to meddle in the internal affairs of the Chinese Communist Party (CCP), Maurer stressed the Romanians' hesitation about playing the mediator:

I don't know what kind of helping hand we could give him. We told him that what we can do is to inform the Chinese leadership about this discussion. We also told him that to our mind there are several problems on which the Chinese leadership has a certain position and for which [the Americans] need to find solutions, and maybe, while searching for these solutions, [the US] could find the path to reach out to and normalize relations with China. One of these problems is Taiwan. ${ }^{38}$

But the most crucial part of the message Maurer delivered did not refer to Nixon's wish to normalize relations with China; indeed, Zhou was already aware of that, since Nixon had made it public after he came into the Oval Office. For Mao and Zhou, the crux of the matter was the possibility of a US-USSR alliance against China, on which they had little if any information. Maurer now sought to reassure the Chinese that, as far as the 'deepening Sino-Soviet rift, Nixon categorically stated that he will by no means support the USSR if Moscow nurtures any aggressive intentions against China. ${ }^{39}$ Maurer underlined that: 
Nixon did not make a secret of his position towards a Sino-Soviet conflict to the Russians. He did not tell it to their faces, but he said it in such a way that his position was made known to the Russians. ${ }^{40}$

In replying to Nixon's peace feelers, Zhou played his cards close to his chest. He neither rebuffed the Romanians nor accepted Nixon's invitation to talk:

As far as relations between China and the US are concerned, you know that there are direct contacts between the Americans and us. You [the Romanians] pointed out correctly that the essence is China's seat at the UN and Taiwan. We've been talking with the Americans on these matters for 14 years. In any case, our position is clear to us, and we know theirs. You pointed out correctly that one day, sooner or later, these matters will have to be solved. ${ }^{41}$

Yet it seems that the message delivered by the Romanians had an important impact, not only on China's coming in from the cold but actually on the deepening Sino-Soviet rift. For Mao and Zhou, the message conveyed through the Romanians, together with an approach by Walter Stoessel, the US Ambassador to Warsaw, to the Chinese chargé, Lei Yang, at a reception in the Polish capital, came as gifts from above.

Days later, a high-level Soviet delegation, after a dizzying to-and-fro between Hanoi, Calcutta and Dushanbe, asked to be received by the Chinese leadership. ${ }^{42}$ The task of meeting with the 'traitors' fell on Zhou. With his usual tact, he broke the news to Alexei Kosygin, the Soviet Premier: China would normalize relations with the USA. $^{43}$ The Soviets' worst fears were materializing: not only had Mao ordered the mobilization of the population in preparation for a war against the USSR, but he was also in cahoots with the Americans. Kosygin went out of his way to persuade the Chinese of Moscow's peaceful intentions. ${ }^{44}$ When he left Beijing, where the Romanian Ambassador was present, the atmosphere was calm and the two leaders shook hands in the presence of journalists and cameramen. By making the meeting public, Mao and Zhou not only showed their willingness to negotiate with the Soviets on border issues for the entire international communist movement to see, but also put pressure on the Americans.

After Kosygin's visit, the Kremlin relented and, for a time, the Soviet propaganda machine muzzled its usual outbursts of anti-Chinese broadcasts, while clashes on the Sino-Soviet border stopped. Yet, revelations by the Western media of Moscow's rumored intentions to launch a pre-emptive attack against Chinese nuclear facilities made Mao and Zhou doubt Moscow's eagerness to solve the Sino-Soviet border dispute through negotiations. ${ }^{45}$ These developments had a powerful impact on the four marshals, who were, once again, tasked with rewriting their report on what the future course of Chinese foreign policy should be. If in March 1969 they advocated an equidistant approach towards the USSR and the US, the latest military clashes convinced them that Beijing should 'play the American card. ${ }^{46}$ Resuming talks in Warsaw was one of the measures advocated by the four marshals, but they made sure to emphasize that no concessions on Taiwan were to be made. The Romanians had proved instrumental for creating the necessary conditions for the Sino-American rapprochement to begin.

On 18 September, the day after the marshals' report, Nixon, taking Ceaușescu's advice about recognizing China's status as a great power, publicly stated at a meeting of the UN Security Council that 'the United States would be glad to exchange views even with Communist China if that country changed its policy of self-isolation. We are prepared to talk 
with the Chinese in the same spirit that we talk with the Soviets. ${ }^{47}$ The Chinese could not have hoped for a better outcome of their strategy: by capitalizing on the contradictions between Washington and Moscow, Beijing managed to force both the US and the USSR to reach out to China. Yet, for Mao, this important achievement was not enough. After the clashes in August, a state of 'war psychosis' took over the Chinese leadership and as a result Mao ordered the population to get ready for an imminent war with the USSR. ${ }^{48} \mathrm{His}$ belief that war with the Soviets was coming stemmed from the fact that the US had not publicly rebuked Moscow's threats of waging nuclear warfare against China, although, as mentioned above, the Romanians had conveyed Washington's opposition to a Soviet attack on China's nuclear facilities. Washington's failure to signal its position fueled Mao's deeply rooted fear that the US and the USSR would strike a deal behind his back and wipe China off the map. ${ }^{49}$

\section{Rewarding the Romanians}

While this incremental but important realigning of great power relations inched forward, Nixon pressed ahead on the nuclear deal with the Romanians. Nixon dispatched his Science Advisor, Dr Lee DuBridge, and the Chairman of the US Atomic Energy Commission, Glenn Seaborg, to Bucharest on 24-27 September and 30 September-2 October, respectively. ${ }^{50}$ It was during Seaborg's visit that Ceaussescu broached the subject of purchasing a nuclear research reactor and a heavy water plant from the United States. ${ }^{51}$

It is necessary here to provide some technical background. The Romanians wanted two pieces of technology for two distinct yet related parts of its nuclear program. First, the research reactor would allow Romanian scientists to perform tests on nuclear fuel for their future nuclear power stations. The necessary HEU, which could also be used for building an atomic bomb (because it was enriched over the level of 93\%), would be supplied by the United States government. ${ }^{52}$ Second, the heavy water plant would produce the coolant and moderator for a power reactor the Romanians wanted to buy from Canada. The Romanians knew they could not purchase this facility without the support of the US government. ${ }^{53}$ Heavy water reactors pose higher proliferation risks than their light water counterparts. To begin with, because these reactors use natural (unenriched) uranium, they were, at the time, under less scrutiny from international institutions in charge of monitoring uranium enrichment. Moreover, the share of plutonium and tritium in the spent fuel produced by these reactors is higher than in light water reactors. At the time, the Romanian leadership was drafting its nuclear procurement strategy, and by 1970, it had decided to build or acquire a pilot reprocessing plant with a capacity of 40 tons/year, in which plutonium could be extracted from spent fuel. ${ }^{54}$ The precursory to this facility was a radiochemistry laboratory, which the Romanians brought up with the Americans in $1972 .^{55}$

Seaborg knew that Romania would not easily obtain these facilities (because of security concerns and red-tape in Washington), but he promised to do his best to help Ceaussescu. Both DuBridge and Seaborg became involved in the Washington-Bucharest-Beijing channel, as it appears that Ceaușescu and Maurer informed them about China's intentions. ${ }^{56}$ Therefore, these two meetings suggest that Ceaușescu's nuclear procurement strategy (using Bucharest's mediation between the US and China to persuade Washington to grant it access to nuclear technology) worked. 
Following these meetings between American officials and the RCP leadership, Nixon and Kissinger took several steps to show Mao and Zhou that they too now understood actions spoke louder than words. On 10 October, Kissinger announced the withdrawal of two US destroyers from the Taiwan Strait, which he portrayed as a considerable concession to Beijing, although the withdrawal seems to have been decided earlier to reduce the Pentagon's expenses. Washington then announced that US naval forces would cease patrolling the Taiwan Strait. ${ }^{57}$ These measures appear to have convinced the Chinese of Nixon's desire to normalize relations with Beijing. On 16 November, Zhou advised Mao that 'we should pay attention to Nixon's and Kissinger's inclinations. ${ }^{58}$

The US-Romania nuclear deal was progressing in tandem with the Washington-Beijing mediation. In late October, at a sumptuous dinner organized by the Romanian Embassy in Washington, DC in honor of the United States Atomic Energy Commission (US AEC) delegation which had just visited Romania, Glenn Seaborg told the Romanian Ambassador, Corneliu Bogdan, that the US government had approved the sale of a heavy water plant to Romania. To Bogdan's delight, Seaborg brought some additional good news: there was no problem with supplying the research reactor the Romanians wanted. ${ }^{59}$ The Romanians were almost there. The heavy water plant appeared to be a breeze: two weeks after the dinner for Seaborg, the Romanian State Council for Nuclear Energy (CSEN) was already receiving representatives of Lummus Company in Bucharest. ${ }^{60}$ CSEN returned the visit in late February 1970, to meet with Seaborg, visit Lummus facilities and discuss matters in more detail. ${ }^{61}$ The Romanians opted for a 'one step at a time' approach in their negotiations for nuclear technology with the US: after having made their intentions about the two facilities known, they focused first on the easiest task (the heavy water plant), and left the research reactor for later.

To expedite negotiations on the nuclear deal, Bucharest worked hard to deliver on its mediation promises, trying to read between the lines of what the Chinese were saying (and doing) and convey it to Washington as accurately as possible. After carefully observing Chinese behavior for several weeks, the Romanians signaled to the Americans that Washington needed to do more to get China to the negotiation table. Mănescu urged the American Ambassador in Bucharest, Leonard Meeker, to change tack with Beijing:

The United States should adopt a practical and realistic policy on China. It is time to provide for the entry of China into the United Nations. China is too large, too populous, and too powerful to leave out of the world organization. There are not two Chinas, but only one. That China must have its proper place and voice in the General Assembly and the Security Council. The United States has been obstructing the seating of the real China in the United Nations, and Peking has obviously registered this fact. The United Nations Charter contains no provision for the membership of Taiwan. Taiwan's purporting to represent China in the United Nations is as if an imposter were seated in the Foreign Minister's office and saying he was Corneliu Mănescu; the situation might last for a time, but sooner or later the imposter would be thrown out. ${ }^{62}$

The American Ambassador was quick to put the blame on China for isolating itself during the Cultural Revolution and for calling it quits in Warsaw. Ironically, just as the two were discussing who was at fault, Lei Yang, the Chinese chargé d'affaires in Warsaw was instructed to receive the American Ambassador to Poland, Walter Stoessel. Before Lei Yang got the chance to do so, Stoessel cornered a Chinese interpreter at a diplomatic 
function and persuaded him to arrange a meeting with the Chinese representative in Warsaw. ${ }^{63}$

To make sure Nixon got the point, Mao also chose to convey the message through multiple channels, relying on the Romanians and the Pakistanis as go-betweens. As far as the Romanian backchannel was concerned, Qiao Guanhua got in touch with the Romanian Ambassador in Beijing. On 9 December, in an awkward fashion meant to disguise Beijing's anxieties at the time, Qiao told Duma that 'it seems the Americans want to resume talks, which had been suspended in February [1969] for which they were at fault. China's position on international talks in general, including those with the Americans, is known and remains in place. $^{64}$ Bucharest understood this as the go-ahead from the Chinese to resume negotiations. Mao got a clue about Washington's views rather quickly, but not through the Romanian or the Pakistani channel. On 11 December, before the Romanians could get back to Beijing about Nixon's reply, Stoessel told Lei Yang that the United States wanted 'greater communication with the People's Republic of China.'65

The Romanians carried out their mediation task with diligence: Deputy Foreign Minister George Macovescu met with Kissinger a week after Duma sent his telegram to convey Beijing's intention to resume contacts with the Americans in Warsaw. ${ }^{66}$ This meeting gave the Romanians the opportunity to stress, once again, the format of the quid pro quo: Romania would serve as a back-channel between Washington and Peking, but in return, it needed the support of the White House with acquiring nuclear technology. ${ }^{67}$ Before conveying the message from the Chinese, Mac (as friends called the Romanian Deputy Foreign Minister) pointed out that Romania wanted to buy a heavy water plant from the US and so requested 'USG [US government] influence in their behalf. ${ }^{68}$ Kissinger got the point:

The AEC permitted the US manufacturer (Lummus Co.) to begin preliminary commercial negotiations with the Romanians, and the Romanians accepted the idea of having [IAEA] safeguards on the plant. [...] The only potential difficulty may be financing. The plant will cost in the neighborhood of $\$ 100$ million. ${ }^{69}$

These messages about the willingness of both the USA and China to resume contacts (passed through the Romanians, the Pakistanis and Stoessel) served to reassure both the Chinese and the Americans that their efforts were not in vain, and so talks in Warsaw were rescheduled for 20 January 1970. As instructed by Nixon, the American Ambassador told Lei Yang that the US was ready to send a high-level official to China if needed. One month later, Lei conveyed Beijing's willingness to receive an envoy to discuss SinoAmerican relations. ${ }^{70}$ The excitement generated by China's positive response was soon overshadowed by a brawl within the administration (White House versus State Department) sparked by the Taiwan question. As a result of this internal quarrel but also due to the worsening of the situation in Cambodia in March 1970, Nixon missed his opportunity. The ousting of Prince Sihanouk from Cambodia by a US-backed general, Lon Nol, triggered a public condemnation from Beijing and resulted in the cancelation of the meeting in Warsaw planned for 20 May 1970. ${ }^{71}$

At this point, the Americans would have been left in the dark had it not been for the Romanians. The Pakistani backchannel was not delivering any messages from Beijing, and the Paris channel was not operational, leaving Nixon and Kissinger with very little insight into what Mao and Zhou were thinking. Luckily for them, in June 1970, the Romanian 
Vice-President, Emil Bodnăraș, stopped over in Beijing on his way to North Korea and, on his return to Bucharest, shared his impressions of developments in Chinese domestic and foreign policy with Ambassador Meeker, who then quickly sent the message forward to Kissinger. ${ }^{72}$ Bodnăraș told Meeker that in his conversation with the Chinese leadership, Mao and Zhou:

carefully downplayed any hostility toward the US, even fudging the record as to who had canceled the Warsaw meetings in order to avoid seeming intransigent. They remarked that you [Nixon] had made some good pre-election statements, but said that you had chosen the path of war, and that for this reason, Sino-US discussions are not useful at this stage. Mao uttered some Delphic aphorisms about the American people not being bad. Despite all this, the Chinese hit very hard at the need for withdrawal of US armed forces from Taiwan and the Taiwan Strait, and otherwise showed no substantive change of position. ${ }^{73}$

As Kissinger noted, the Chinese adopted a 'relatively moderate line, with possible elements of flexibility. Zhou Enlai also spoke of a relationship based on the principles of peaceful coexistence. ${ }^{74}$ The Romanians' efforts proved to the USA not that they were keen to help, but that they could deliver information to Washington that was not available through other channels of communication.

To spur the Americans further, Bodnăraș also touched on an apparently new approach adopted by the Chinese vis-à-vis the Soviets: Mao himself asked Bodnăraș 'to convey friendly greetings to Kosygin, and Kosygin replied. ${ }^{75}$ Criticizing the USSR on the issue of peaceful coexistence was a thing of the past; the new bone to pick was the Brezhnev doctrine. ${ }^{76}$ Bodnăraș also reiterated Romania's interest in carrying messages between Washington and Beijing, an opportunity at which Nixon jumped right away. On 18 July 1970, two weeks after Meeker reported on his meeting with Bodnăraș, Nixon met with Foreign Minister Mănescu to discuss prospects for improving relations between the USA and China. Mănescu told Nixon that the Romanian Ambassador to Beijing was returning to China under instructions 'to take soundings there on this subject. He anticipates that some signs of Chinese thinking would emerge. ${ }^{77}$ Sino-American relations were not beyond repair.

To a certain extent, it was now more of the same dynamics that had defined these budding contacts from their inception: a stubborn emphasis on the issue of Taiwan, and China's representation at the UN. The new element was the presence of Prince Sihanouk in Beijing (in exile), which precluded the Chinese from engaging with the Americans publicly. With the Warsaw talks on the back-burner, the Romanian backchannel became ever more important. This explains why Nixon proved so eager to receive Ceaușescu at very short notice for a private meeting in the Oval Office on 26 October 1970. Nixon, while perfectly aware that Ceaușescu was expecting to be compensated for the mediation services he provided, asked him to convey an invitation to the Chinese to exchange high personal representatives. ${ }^{78}$ Ceaușescu readily accepted. Nixon noted that 'Ceaușescu's continued role as a peacemaker is very useful in regard to US-Chinese relations. He can talk to both parties which is very helpful and in the end, in the President's opinion, this will produce results. ${ }^{79}$

This expression of gratitude might have given Ceaușescu a chance to push for the nuclear deal, but he decided to save it for later, as there had been a minor change of plans in Bucharest's nuclear acquisition program. On 14 October, the chargé d'affaires at the Romanian Embassy in Washington, DC, Gheorghe loniţă, had informed Seaborg that 
Bucharest had decided to put on hold its negotiations for the heavy water plant with Lummus Company, without giving any clues about the Romanians' volte-face. ${ }^{80}$

Ceaușescu now channeled all his energy into purchasing the nuclear research reactor. To make sure he obtained it, he stepped up the mediation efforts. In this respect, he sent Gheorghe (Gogu) Rădulescu, the Vice-President of the Romanian Council of Ministers, to Beijing for meetings held during November 20-26. The prompt response given by the CCP leadership to disastrous floods that had submerged entire swathes of land in southern and western Romania in the spring of 1970 gave Rădulescu a good pretext to pay a 'thank you' visit to the People's Republic of China (PRC). After dealing with the logistical aspects of the economic assistance the CCP had offered as humanitarian relief, Rădulescu moved on to international affairs. He told Zhou Enlai about Nixon's and Secretary of State William Rogers' preoccupation with finding ways to normalize relations between the USA and China. Trying to signal the Americans' flexibility and interest, Rădulescu emphasized Nixon's availability to 'discuss anything, anytime, and anywhere, to improve Sino-American relations. ${ }^{81}$ Given that holding talks in Warsaw had become problematic due to the Poles' and Soviets' constant surveillance of American and Chinese diplomats, however, Nixon proposed changing the venue. Zhou Enlai quickly rebuffed the suggestion: the problem was not the venue, but the issue of China's representation at the UN and Taiwan. But the Chinese did pull back from the intransigent position they had adopted in the aftermath of the US invasion of Cambodia. Although they had offered shelter to the deposed Prince Sihanouk, they realized that they could not let the issue of Cambodia derail their entire foreign policy. As a result, Zhou Enlai proved far more accommodating than the Romanians had expected:

If Nixon indeed wants and has the ability to solve this problem, then the Chinese government would salute the coming to Beijing of a US special envoy. Even Nixon, not just a special envoy, can come to Beijing. He went to Bucharest and Belgrade, why not Beijing ${ }^{82}$

\section{On the verge of fiasco}

The watershed CCP decision to invite the US President to visit China (before any president had paid such a visit to the USSR) carried profound implications for the Romanians and the potential rewards they could reap from the Americans for delivering such an important message. Ceaușescu was on a trip to Morocco, so the message had to wait until he returned. On 14 December, two days after submitting the report of the visit to Beijing to the registry of the RCP Central Committee, Rădulescu met with Ambassador Meeker to let him know about his visit to China. The only hint Rădulescu could give Meeker, without Ceaușescu's approval, was that Zhou Enlai would not come to Romania, so a meeting between a US diplomat and the Chinese premier in Bucharest was out of the question.

At that point, Zhou Enlai's invitation had already reached Nixon and Kissinger through the Pakistani Ambassador to Washington, DC, who delivered the message on 9 December. Some scholars see the Romanians' blunder as the reason that Nixon began relying on the Pakistani channel. ${ }^{83}$ Additional primary documents, however, suggest a different interpretation. Bucharest's delay did not lead to Nixon losing interest in the Romanian backchannel to Beijing, since the Romanians could offer 
vital information not only about the Chinese, but also about the Soviets, to whom the Pakistanis had limited access. ${ }^{84}$ Two weeks after Rădulescu's meeting with Meeker, Gen. Alexander Haig, one of Kissinger's aides within the National Security Council, met with the Romanian Ambassador to Washington, DC, Corneliu Bogdan, who had just been summoned to Bucharest to be briefed on Zhou Enlai's message. Haig told Bogdan that the US eagerly awaited Romania's assessment of Soviet reactions to the feelers Nixon had put out to China. ${ }^{85}$ Haig made sure to dangle the carrot of increased trade with Romania, which included the TRIGA nuclear reactor deal, before bringing up the subject of China. ${ }^{86}$

The Romanians transmitted Zhou Enlai's invitation on 11 January $1971 .{ }^{87}$ The risks of doing so ran high: if the Soviets realized the Romanians had facilitated the Sino-American rapprochement, which to some in Moscow meant the creation of a common front against the USSR, they would have severely punished Ceaușescu. ${ }^{88}$ The RCP leadership, however, decided to play this dangerous game of Russian roulette. First, they asked for the TRIGA reactor, and then they delivered Zhou Enlai's response. ${ }^{89}$ Nixon, however, played for time as he wanted to extract more from the Romanians before he gave the green light to the research reactor sale. He also tried to keep the Chinese on their toes, so he instructed Kissinger to 'cool it.' ${ }^{\prime 0}$

If the Pakistani channel proved to be a more reliable conduit between Washington and Beijing, the Romanians remained a useful source of information and Nixon continued to rely on them. Shortly after the 11 January encounter, Kissinger received Bogdan again and inquired about Taiwan, in an attempt to find out how willing the Chinese were to negotiate in earnest. Bogdan remained tight-lipped, and instead, asked about the necessary changes to US legislation that would allow trade with Romania to flourish and eliminate export controls, including the ones that applied to the sale of the nuclear research reactor, implying that the Romanians would provide the USA with the information they coveted only if Bucharest's demands were met. ${ }^{91}$ Kissinger blamed the bureaucracy for the delay and promised Bogdan that the desired adjustments would be made shortly. The Romanians would soon learn that believing the Americans' promises could put Bucharest on the spot.

\section{Towards visible successes}

Less than a month after this meeting, the military operations the USA launched in February 1971 in Laos appeared to imperil the Romanians' mediation efforts once again. ${ }^{92}$ From the very beginning, they had pleaded the case with their Chinese counterparts that Sino-American relations could be normalized because Nixon was 'a man of peace. ${ }^{93}$ Now, with Nixon appearing as a warmonger, Beijing questioned Romania's 'reliability and good faith. ${ }^{94}$ But this turn of events did not result in the Chinese cutting off the Romanians as a source of information and channel of communications. In March 1971, when Gogu Rădulescu returned to Beijing for additional economic and political negotiations, Zhou Enlai told the Romanian Vice-President that 'China has nothing to talk about with the United States,' because they were poles apart on key matters such as the situation in Indochina and Taiwan. ${ }^{95}$ The two sides had not made any significant progress since Nixon's response to Zhou Enlai's invitation in December $1970 .^{96}$ Then, by a stroke of luck, the Americans had an opportunity to sound out Beijing again. Mao's eagerness to engage in 'Ping-Pong diplomacy,' manifested in his invitation and warm reception of the US table 
tennis team to China, signaled to Nixon and Kissinger that not all hope was lost. ${ }^{97}$ For a brief period, public diplomacy put secret negotiations in the shade.

The Romanian channel was used again in late April, when the Americans put forward a bold initiative: a hotline between the Oval Office and Zhongnanhai (an imperial garden where Mao's villa was located at the time). The young Donald Rumsfeld, then the President's counselor on special trade - whom Nixon described as a 'ruthless little bastard' paid a secret visit to Bucharest on 27 April $1971 .{ }^{98} \mathrm{He}$ asked the Romanian officials to convey to the Chinese leadership Nixon's desire to carry out negotiations with Beijing through a channel different than the one in Warsaw. Nixon, according to Rumsfeld, had a direct line of communications in mind, outside the purview of the Department of State. A hotline would preclude Rogers (and some members of the pro-Taiwan lobby in Washington, DC) from derailing these incipient contacts. ${ }^{99}$ In addition to preventing leaks and keeping saboteurs at bay, a hotline would also help greatly with the practicalities involved in the exchange of high-level envoys, an initiative which regained impetus with a message that Agha Hilaly, the Pakistani Ambassador to Washington, DC, delivered on 27 April on Zhou Enlai's behalf. The archival record does not offer any evidence that the Romanians had passed on to the Chinese the message delivered by Rumsfeld. Nixon, however, tried to make sure that Rumsfeld had the Romanians' ear by sending his Secretary of Commerce, Maurice Stans to Bucharest from 25 to 27 April. ${ }^{100}$ Stans broke the good news to Ceaușescu: Nixon had ordered a relaxation of export control regulations that affected Romania. ${ }^{101}$ To Nixon's mind, improvements in trade relations, including the provision of sensitive nuclear assistance, such as the significant quantity of HEU, would be enough of an incentive to ensure the Romanians' cooperation on geopolitical issues that concerned Washington - the opening to China being at the top of the agenda.

For Ceaușescu, Nixon's shift on trade with Romania was the ultimate proof that his strategy to capitalize on his middleman role to obtain nuclear technology worked. As a consequence, when Kissinger asked Ceaușescu, through Ambassador Bogdan, to reiterate Washington's willingness to improve relations with the PRC, Ceaussescu jumped at the opportunity. Unfortunately, Nixon's National Security Adviser was too slow in sending a more substantive message to the Chinese on the occasion of Ceaușescu's visit to Beijing in June 1971. ${ }^{102}$ Nonetheless, Ceaușescu's trip to China provided the Americans with a window into Mao and Zhou Enlai's thinking.

Although at this point the Pakistani channel was the preferred conduit for messages related to Kissinger's visit to Beijing, neither Washington nor Beijing could afford to cast the Romanians aside. ${ }^{103}$ Ceaușescu and his top aides possessed valuable intelligence not only about the intentions of both the Chinese and the Americans, but also about the USSR, which could interfere with the Sino-American rapprochement. Per Kissinger's request, during his visit to Beijing, Ceaușescu repeated that Nixon was serious about normalizing relations with the PRC. Knowing that the situation in Indochina would be a sticking point for any Sino-American direct talks, Ceaușescu also underlined Nixon's desire to reach an agreement on total withdrawal from Laos and to end the war in Vietnam. ${ }^{104}$ Mao and Zhou Enlai emphasized that they were ready to receive Nixon, but warned the Americans that the main problem remained Taiwan. In this respect, Ceaușescu elicited important information from Mao and Zhou Enlai about the Chinese position on Taiwan: according to Beijing, it was not the USA, but Japan that wanted to occupy Taiwan. Therefore, China's criticism of the USA was not so much about the presence of American forces 
in Taiwan; rather it was directed against Washington's willingness to let the militarist Japanese replace them in Asia. ${ }^{105}$ This Chinese position added an extra layer of complexity to an already complicated situation.

For the Romanians, however, the rewards started flowing in. While Ceaușescu duly carried out his part of the deal, the Americans delivered on their promises to help Romania's nuclear program. In June 1971, seeing that Nixon relaxed export control regulations visà-vis Romania, Gulf General Atomic, the TRIGA nuclear research reactors supplier the Romanians had in mind, sent a delegation to Bucharest for talks. ${ }^{106}$ The negotiations made headway, leaving the final say with the US government, first with the US AEC and ultimately with the White House. Yet, before giving the go-ahead, Nixon had one more item to tick off his to-do list: finding out what Ceaușescu had talked to Mao and Zhou Enlai about.

Nixon found the Romanians' feedback about the Chinese very satisfying. Even after his secret trip to Beijing in July 1971, Kissinger still relied on the Romanians to learn more about what the Chinese had in mind for Nixon's upcoming visit, which is why, on 31 August, he received Ambassador Bogdan in San Clemente. The omens were good. Bogdan reported that Ceaușescu and Mao 'had talked about the US on a constructive basis.' ${ }^{107}$ Then, Kissinger hunted for clues about China's role in Vietnam, the Taiwan question, Japan, and Beijing's fears of a Soviet attack, which Bogdan dutifully provided.

In exchange for all these efforts, the Romanians finally got their reward when on 20 September 1971, Glenn Seaborg and loan Ursu, CSEN's president, signed the extension of the 1969 Nuclear Cooperation Agreement between the USA and Romania. This agreement referred to the transfer of not only nuclear materials and know-how, but also of entire facilities such as the TRIGA nuclear research reactor. ${ }^{108}$ With the agreement signed, Ceaușescu met with Seaborg privately, and provocatively presented his nuclear hedging strategy. 'Romania was not planning to undertake anything for military purposes, at least not for the time being,' he confessed. ${ }^{109}$ In other words, the nuclear technology Romania just acquired from the USA could later constitute the basis for a nuclear weapons program. Seaborg noted the difference between Ceaușescu's statements in 1969 and his attitude in 1971: 'You added "for the time being." I remember that in our conversation from two years ago you did not include such an addition.' The Romanian leader explained the shift in his position by pointing to the intensification of the arms race: 'Of course, sooner or later, if the efforts to build up nuclear stockpiles do not stop, other states will join the race, including small states.' Seaborg reminded Ceaușescu about Romania's commitment not to acquire nuclear weapons, made when it signed the NPT. 'The treaty did not achieve much,' Ceaușescu replied. ${ }^{110}$ He listed several countries that he considered threshold nuclear powers - India, Brazil, Japan, West Germany, Israel and South Africa - and pointed out that acquiring nuclear weapons depended on the financial resources a country had at its disposal. 'Other states are making progress [towards nuclear weapons], even those that start from a low level of economic development,' the Romanian leader emphasized, obliquely referring to a point in the future when Romania, a developing country, might do so as well. ${ }^{111}$ Seaborg admitted that the issue of disarmament was very important and reassured Ceaușescu that the USA and the USSR were taking steps in that direction through the Strategic Arms Limitation Talks. Yet, superpower negotiations on disarmament were not enough for Ceaușescu. There were other countries that possessed and 
developed nuclear weapons - the United Kingdom, France and 'especially China,' he told Seaborg. 'What do you think we should do about China?' the American official asked. ${ }^{112}$ Ceaușescu replied that the first step was the normalization of relations between Washington and Beijing, which was, in no small part, possible thanks to Romania's efforts. This rapprochement had 'already started and was progressing well.'113 Bringing up the issue of Nixon's opening to China in the context of US-Romanian nuclear cooperation underlines the quid pro quo between Bucharest's mediation between Beijing and Washington, and American nuclear technology transfers.

Ceaușescu's nuclear hedging, which he made clear to Seaborg, did not hinder the sale of American nuclear technology to Romania. The Nixon administration, instead of preventing the transfer of the TRIGA reactor in light of Ceaușescu's efforts to keep the nuclear option open, intensified nuclear cooperation with Romania. Shortly after Seaborg's visit to Bucharest, on 4 October 1971, Kissinger confirmed the White House's green-light for Romania's purchase of the TRIGA nuclear reactor from Gulf General Atomic. ${ }^{114}$ This episode refocuses the historiographic lens on the (non-)proliferation concerns driving the Sino-American rapprochement: to better manage the emerging nuclear order, the United States had to recognize China as a nuclear weapon state. But to reach out to Beijing, Nixon had to allow smaller, peripheral actors like Nicolae Ceaușescu to chip away at the non-proliferation regime with his nuclear hedging strategy. Surely, China, as a nuclear power, could have done more damage than Romania, who had only a small research reactor in operation at the time of the Sino-American rapprochement. Nixon's decision to provide nuclear assistance to Bucharest sat well with the decades-long 'foot-in-the-door' US non-proliferation policy: Ceaușescu or his successors might decide to launch a nuclear weapons program whether Washington liked it or not; it was therefore in the US interest to be involved in the Romanian nuclear program to retain some leverage over Bucharest, a position reiterated years later, when the Romanians were shopping for reprocessing technology. ${ }^{115}$

\section{Conclusion}

Two years of relaying messages between Washington and Beijing paid off: the Romanians were soon to become the first country in the Warsaw Pact to buy from the United States a nuclear facility of this size and scope. At the beginning of these negotiations for nuclear technology, the odds were stacked against the Romanians. Bucharest was not only a member of a military alliance that regarded the United States as the 'principal adversary', but it also embraced a social, economic and political system that was completely at odds with that of the capitalist United States. Moreover, Romania lacked a convertible currency which meant that its ability to pay for the nuclear reactor depended on the viability of its exports (which could earn it hard currency). The Romanians insisted on including a barter dimension in the nuclear reactor deal, which most suppliers were not too eager to pursue. The mediation services Ceaușescu could provide to an embattled US canceled out the effect of Romania's military and ideological affiliation and its financial constraints.

Ceaușescu could not have hoped for a better negotiating partner than Nixon. As soon as the US President threw his weight behind the TRIGA reactor deal with Bucharest, Bucharest got what it wanted. As Francis Gavin shows, 'neither Nixon nor Kissinger thought halting nuclear proliferation merited sacrificing other geopolitical goals. ${ }^{116}$ However, as this episode suggests, proliferators came in different shapes 
and sizes, with China ranked at the top of the priority list. Enabling Romania to maintain a nuclear hedging strategy did not appear as dangerous as shunning Beijing.

\section{Notes}

1. Or Rabinowitz, Bargaining on Nuclear Tests: Washington and its Cold War Deals (Oxford: Oxford University Press, 2014).

2. John Wilson Lewis and Xue Litai, China Builds the Bomb (Stanford: Stanford University Press, 1988), 36-7; Francis J. Gavin, Nuclear Statecraft: History and Strategy in America's Atomic Age (Ithaca: Cornell University Press, 2012), 76.

3. William Burr and Jeffrey T. Richelson, 'Whether to "Strangle the Baby in the Cradle"', International Security, xxv (Winter 2000/2001), 54-99; Gavin, Nuclear Statecraft, 76.

4. Lyndon Baines Johnson Presidential Library, National Security File, Committee File, Committee on Nuclear Proliferation, box 4, Alternative Courses of Action, Permissive or Selective Proliferation [December 1964], 3. On China as a 'legitimate' nuclear weapon states under the NPT, see Sharon A. Squassoni, Steven R. Bowman, Carl E. Behrens, Proliferation Control Regimes: Background and Status (New York: Nova Science Publishers, 2003), 15; Nicola Horsburgh, China and the Global Nuclear Order. From Estrangement to Active Engagement (Oxford: Oxford University Press, 2015), 18.

5. Arhivele Naționale Istorice Centrale [henceforth ANIC], Comitetul Central al Partidului Comunist Român [CC PCR], Relații Externe, 15/1967, Minutes of conversation between Nicolae Ceaușescu and Richard Nixon, 22 March 1967, 19.

6. Sensitive nuclear assistance, as defined in the literature, can include the transfer of enrichment or reprocessing facilities, nuclear weapons design information, or weapons-grade nuclear materials. Matthew Kroenig, Exporting the Bomb. Technology Transfer and the Spread of Nuclear Weapons (Ithaca and London: Cornell University Press, 2010), 10-11. Weapons-grade fissile material is measured in significant quantities (SQ), which the IAEA defines as 'the approximate quantity of nuclear material in respect of which, taking into account any conversion process involved, the possibility of manufacturing a nuclear explosive device cannot be excluded'. The cut-off point for a significant quantity of Highly Enriched Uranium (HEU) is at $25 \mathrm{~kg}$. International Atomic Energy Agency, Against the Spread of Nuclear Weapons, available at: https:// www.iaea.org/Publications/Booklets/Safeguards/index.html.

7. By 1970, the Romanians had decided to master the plutonium fuel cycle, and build (or buy) a pilot reprocessing plant with a capacity of 40 tons/year. Arhivele Ministerului Afacerilor Externe [AMAE], 241/12.A.39/1970-1971, Setting-up a Nuclear Technology Institute in Romania, Note from CSEN Vice-President Emilian Rodean to the Deputy Foreign Minister Nicolae Ecobescu, 29 Dec. 1970, 30, 36. Before building a pilot reprocessing plant, the Romanians wanted to acquire more experience by operating a radiochemistry laboratory. The idea of purchasing such a facility from the United States was first broached by the Romanians shortly after the mediation between Beijing and Washington, in 1972. National Archives and Records Administration [henceforth NARA], Record Group 59 [henceforth RG 59], Subject Numeric Files, 1970-1973. Science, From AE 13 Japan to AE Swe-US, box 2870, Airgram A-7379 from the US Department of State to the US Atomic Energy Commission, 21 July 1972.The negotiations over this radiochemistry laboratory matured in the mid- and late-1970s and culminated with France sealing a deal with Bucharest. Given the different timeframe in which these talks took place, the acquisition of this facility falls outside the scope of this article.

8. Eliza Gheorghe, 'Atomic Maverick: Romania's negotiations for nuclear technology, 1964-1970', Cold War History, xiii (2013), 373-92.

9. Mihai Croitor, Romania și Conflictul Soviet-Chinez (1956--1971) (Cluj-Napoca: Editura Mega, 2009), 343-61; Mircea Munteanu, 'Communication Breakdown? Romania and the Sino-American Rapprochement', Diplomatic History, xxxiii (2009), 615-31.

10. The HEU Romania secured from the USA qualifies as weapons-grade, as it contained $93 \%$ of the U235 isotope. The material was under IAEA safeguards, but this provision did not stop the Romanians from carrying out unreported experiments using US-supplied uranium and the 
radiochemistry laboratory they purchased from France. NARA, RG 59, Subject Numeric Files, 1970-1973, Science, AE 13 IAEA 1970-1972, box 2866, Telegram from the Department of State to the US Mission to IAEA, Vienna, 8 March 1973; International Atomic Energy Agency Archives, Sven Thorstensen and Garry Dillon, Report on Special Inspection in Romania, 14 May 1992, 5-6.

11. Richard Nixon Presidential Library [henceforth RNPL], Series II: Trip File, Wilderness Years, File: Bucharest, Romania, 22-23 March 1967, box 9, Memorandum of conversation between Former Vice President Nixon and RCP Secretary General Ceaușescu, 22 March 1967.

12. ANIC, CC PCR, Relaţii Externe, 15/1967, Minutes of conversation between Nicolae Ceaușescu and Richard Nixon, 22 March 1967, 16-23.

13. Idem, 16-18.

14. ANIC, CC PCR, Relații Externe, 14/1967, Minutes of the meeting between the Romanian Communist Party delegation, formed of Nicolae Ceaușescu, lon Gheorghe Maurer, Paul NiculescuMizil, and the Communist Party of the Soviet Union delegation, formed of Leonid Brezhnev, Alexei Kosygin, Yuri Andropov, Andrei Gromyko, 17-18 March 1967, 66.

15. Eli Levite discusses the term 'standby capability' in 'Never Say Never Again: Nuclear Reversal Revisited', International Security xxvii (2002/2003), 66.

16. AMAE, Telegrams from Beijing, vol. II, 1969, Telegram from Aurel Duma to Corneliu Mănescu, 13 May 1969, 56201, 24-8, published in Romulus loan Budura, Relațiile Româno-Chineze, 18801974. Documente (Bucharest: Arhivele Naționale ale Ministerului Afacerilor Externe, 2005), 918.

17. Idem, 919.

18. Polish-Soviet Talks in Moscow, 1 March 1969, source: Andrzej Paczkowski (ed), Tajne Dokumenty Biura Politycznego PRL-ZSRR, 1956-1970 (London: Aneks Publishers, 1996). Translated for CWIHP by Malgorzata K. Gnoinska; available at: http://digitalarchive.wilsoncenter.org/docu ment/112937

19. The archival records in Romania do not specify the names of these senators. It is plausible that the Romanians were acting as a messenger on behalf of Senator Mike Mansfield, who sent a letter to Beijing (written in close coordination with the White House) on 17 June. Lorenz Lüthi, 'Restoring Chaos to History: Sino-Soviet-American Relations, 1969', The China Quarterly, ccx (2012), 388.

20. AMAE, Telegrams from Beijing, vol. II, 1969, Telegram from Aurel Duma to Corneliu Mănescu, 3 June 1969, 56228, 74-7, published in Budura, Relațiile Româno-Chineze, 921.

21. Ibid.

22. Ibid.

23. Quoted in Lüthi, 'Restoring Chaos', 383.

24. Idem, 385.

25. 'A preliminary assessment of the possibility of war,' Excerpts of the report to Mao by a special group headed by Chen Yi, the Foreign Minister, 11 July 1969; edited by Xiong Xianghui, Beijing, Liaowang, August 1992, published in Barbara Barnouin, Yu Changgen, Chinese Foreign Policy During the Cultural Revolution (London and New York: Kegan Paul International, 1998), 139-42.

26. Lüthi, 'Restoring Chaos,' 389.

27. NARA, Nixon Presidential Materials [NPM], National Security Council [NSC] Files, USSR vol. III June-July 1969, box 711, Memorandum for Henry A. Kissinger, 24 June 1969, quoted in ibid.

28. NARA, NPM, NSC, President's Trip Files, box 454, Memorandum for the President from Kissinger, (July 1969).

29. Paschalis Pechlivanis, 'Between Détente and Differentiation: Nixon's Visit to Bucharest in August 1969', Cold War History. xxvii (2017), 250.

30. NARA, NPM, NSC Files, Presidential/HAK MemCons, box 1023, Memorandum of conversation between President Richard M. Nixon and President Nicolae Ceaușescu, 2 Aug. 1969.

31. Romania's involvement in the Vietnam War excluded it from a series of financial benefits the USA could grant.

32. NARA, NPM, NSC Files, Presidential/HAK MemCons, box, 1023, Memorandum of conversation between President Richard M. Nixon and President Nicolae Ceaușescu, 2 Aug. 1969. A similar proposal had been made to Pakistan around the same time. Kulik, Sovetsko-Kitaiski Raskol: Prichiny i Posledstviia (Moscow: Institut Dal'nevo Vostoka RAN, 2000), 457. 
33. NARA, NPM, NSC Files, Presidential/HAK MemCons, box 1023, Memorandum of conversation between President Richard M. Nixon and President Nicolae Ceaușescu, 2 Aug. 1969.

34. Ibid.

35. ANIC, CC PCR, Relații Externe, 40/1969, Minutes of conversation between Nicolae Ceaușescu and Zhang Haifeng, the Chinese Ambassador to Bucharest, 24 June 1969.

36. AMAE, Telegrams from Beijing, vol. II, 1969, Telegram from Aurel Duma to Corneliu Mănescu, 18 July 1969, 56312, 212-3, published in Budura, Relațiile Româno-Chineze, 928; ANIC, CC PCR, Relaţii Externe Alfabetic [Alphabetic], 4C/1966, Letter from Mao Zedong, Zhou Enlai to Nicolae Ceaușescu, lon Gheorghe Maurer, 20 Aug. 1969, 115.

37. AMAE, Telegrams from Beijing, vol. II, 1969, Telegram from Aurel Duma to Corneliu Mănescu, 22 Aug. 1969, 56348, 262-3, published in Budura, Relațiile Româno-Chineze, 938.

38. ANIC, CC PRC, Relații Externe, 72/1969, Minutes of conversation between the Romanian delegation led by lon Gheorghe Maurer and the Chinese delegation led by Zhou Enlai and Li Xiannian, 7 Sep. 1969, 7.

39. Idem, 8.

40. Ibid.

41. Idem, 28.

42. Idem, 31; NARA, RG 59, Central Foreign Policy Files [CFPF], 1967-1969, Political and Defense, POL 2 ROM to POL 7 ROM, box 2450, Airgram 260, Political Notes, 6 Sep. 1969.

43. Lüthi, 'Restoring Chaos,' 392.

44. German V. Kireev, Rossiya-Kitai. Neizvestnye stranitsy pogranichnykh peregovorov (Moscow: Rosspen, 2006), 94-103.

45. Boris Koloskov, Vneshnyaya politika Kitaya, 1969--1976 (Moscow: Politizdat, 1977), 66-9.

46. Report to the CCP Central Committee, Further Thoughts by Marshal Chen Yi on Sino-American Relations, 17 Sep. 1969. Source: Zhonggong dangshi ziliao, no. 42, 86-7. Translated for CWIHP by Chen Jian, available at: http://digitalarchive.wilsoncenter.org/document/117155; Vladimir P. Fedotov, Polveka vmeste s Kitaem. Vospominaniya, zapisi, razmyshleniya (Moscow: Rosspen, 2005), 375-6; Lüthi, 'Restoring Chaos', 393.

47. FRUS 1969--1976, vol. xxix, Eastern Europe; Eastern Mediterranean, 1969-1972, Memorandum of conversation between Richard Nixon and Romanian Foreign Minister Corneliu Mănescu, New York, 18 Sep. 1969, 460-4.

48. Oleg B. Borisov and Boris T. Koloskov, Sovetsko-Kitaiskie Otnosheniya, 1945--1980 (Moscow: Mysl', 1980), 437; lurii M. Galenovich, Rossiysko-Kitaiskie Otnosheniya. Konets XIX - nachalo XXI v. (Moscow: Institut Dal'nevo Vostoka RAN, 2007), 147.

49. Lüthi, 'Restoring Chaos', 393-4.

50. NARA, NPM, NSC Files, Country Files - Europe, Rumania, vol. I - 8-69 to Rumania vol. II 9/69 June 70, box 702, Telegram from Lee DuBridge for Secretary Rogers, 29 Sep. 1969; LOC, Manuscript Division, Glenn Seaborg Papers, Romania File, box 736.

51. LOC, Manuscript Division, Glenn Seaborg Papers, Romania File, box 736; ANIC, CC RCP, Economic Section, 19/1969, Memorandum from the Nuclear Energy Committee, 11 Sep. 1969, $13-4$.

52. AMAE, 212/1969, The Visit of Dr. Glenn Seaborg, the President of the US AEC to Romania, Telegram from the Romanian Ministry of Foreign Affairs to the Romanian Embassy in Washington, DC, 21 Oct. 1969, 9.

53. AMAE, 212/1969, The Visit of Dr. Glenn Seaborg, the President of the US AEC to Romania, Note from the State Committee for Nuclear Energy to Corneliu Mănescu, 16 Sep. 1969, 3.

54. AMAE, 241/12.A.39/1970-1971, Setting-up a Nuclear Technology Institute in Romania, Note from CSEN Vice-President Emilian Rodean to the Deputy Foreign Minister Nicolae Ecobescu, 29 Dec. 1970, 30, 36.

55. NARA, RG 59, Subject Numeric Files, 1970-1973. Science, From AE 13 Japan to AE Swe-US, box 2870, Airgram A-7379 from the US Department of State to the US Atomic Energy Commission, 21 July 1972. 
56. NARA, NPM, NSC Files, Country Files - Europe, Rumania, vol. iii July 1970-Dec. 1971 to Rumania vol. iv Jan. 1972, box 703, Memorandum for Henry A. Kissinger, from Theodore Eliot, Jr., 14 July 1970.

57. Gong Li, 'Chinese Decision Making and the Thawing of U.S.-China Relations' in Robert S. Ross and Changbin Jiang (eds), Re-examining the Cold War: U.S.-China Diplomacy, 1954-1973 (Boston, MA: Harvard University Asia Center, 2001), 337.

58. Lüthi, 'Restoring Chaos', 395.

59. AMAE, 212/1969, Washington, The Visit to the Socialist Republic of Romania of Glenn Seaborg, the Chairman of the US Atomic Energy Commission, 11.

60. ANIC, CC PCR, Secția Economică, 23/1970, Report on the acquisition of nuclear power plants and adjacent facilities, 2 Feb. 1970, 40.

61. LOC, Manuscript Division, Glenn Seaborg Papers, Romania File, box 736.

62. NARA, NPM, NSC Files, Country Files - Europe, Rumania, vol. i - 8-69 to Rumania vol. ii 9/69 June 70, box 702, Memorandum for the Under Secretary of State from the US Ambassador to Bucharest, 1 Dec. 1969, Top Secret.

63. Lüthi, 'Restoring Chaos', 395; MacMillan, Nixon and Mao, 170.

64. AMAE, Telegrams from Beijing, vol. iii, 1969, Telegram from Aurel Duma to Corneliu Mănescu, 10 Dec. 1969, 56556, 329-332, in Budura, Relațiile Româno-Chineze, 989.

65. Margaret MacMillan, Nixon and Mao: The Week that Changed the World (New York: Random House, 2008), 170.

66. NARA, NPM, NSC Files, Country Files - Europe, Macovescu (Romania) to Spain vol. i thru Feb. 70, box 704, Summary Points of Kissinger's Conversation with Macovescu, 18 Dec. 1969. The message was reiterated two days later by the Pakistani Ambassador to the US in a meeting with Kissinger.

67. The Romanians also requested assistance in other domains, such as agriculture, fossil fuels or industrial plants. The archival evidence indicates, however, that nuclear technology ranked highest on their priority list. As the minutes of conversation note, 'they attach particular attention to this [nuclear] question.' NARA, NPM, NSC Files, Country Files - Europe, Macovescu (Romania) to Spain vol. i thru Feb. 70, box 704, Memorandum of conversation between Gheorghe Macovescu and Henry A. Kissinger, 16 Dec. 1969.

68. NARA, NPM, NSC Files, Country Files - Europe, Macovescu (Romania) to Spain vol. i thru Feb. 70, box 704, Summary Points of Kissinger's Conversation with Macovescu, 18 Dec. 1969.

69. NARA, NPM, NSC Files, Country Files - Europe, Macovescu (Romania) to Spain vol. i thru Feb. 70, box 704, Talking points.

70. MacMillan, Nixon and Mao, 170.

71. The Romanians also condemned the US but they did so with a view to keeping 'a channel open to communist countries of S.E. Asia in interest of an eventual peaceful solution of conflict; this would enable Romania someday to play a useful role. Romania obviously cannot serve as a US agent, but it could help in securing peace, a peace which Maurer said he knows US also wants.' NARA, NPM, NSC Files, Country Files - Europe, Rumania, vol. i - 8/69 to Rumania vol. ii 9/69 - June 70, box 702, Telegram from Leonard Meeker to Secretary Rogers, 8 May 1970.

72. NARA, NPM, NSC Files, Country Files - Europe, Rumania, vol. i - 8/69 to Rumania vol. ii 9/69 June 70, box 702, Memorandum for Henry A. Kissinger, from Theodore Eliot, Jr., 14 July 1970; NARA, NPM, NSC, Country Files - Europe, Rumania, vol. iii July 1970 - Dec. 1971 to Rumania vol. iv Jan. 1972, box 703, Memorandum for the President from Henry Kissinger, 4 Aug. 1970.

73. NARA, NPM, NSC Files, Country Files - Europe, Rumania, vol. iii July 1970 - Dec. 1971 to Rumania vol. iv Jan. 1972, box 703, Memorandum for the President from Henry Kissinger, 4 Aug. 1970.

74. Ibid.

75. Ibid.

76. Ibid.

77. NARA, NPM, NSC Files, Country Files - Europe, Rumania, vol. iii July 1970-Dec. 1971 to Rumania vol. iv Jan. 1972, box 703, Telegram from Meeker to Rogers, 18 July 1970. 
78. NARA, NPM, NSC Files, VIP Visits, Romania Ceaușescu Visit Oct. 1970 to Romania Pres Ceaușescu Visit Dec. 1973, box 936, Memorandum for Kissinger from Helmut Sonnenfeldt, 25 Oct. 1970; NARA, NPM, NSC Files, Country Files - Europe, Rumania, vol. iii July 1970-Dec. 1971 to Rumania vol. iv Jan. 1972, box 703, Memorandum of conversation between President Nixon and President Nicolae Ceaușescu, 26 Oct. 1970.

79. NARA, NPM, NSC Files Country Files - Europe, Rumania, vol. iii July 1970-Dec. 1971 to Rumania vol. iv Jan. 1972, box 703, Memorandum of conversation between President Nixon and President Nicolae Ceaușescu, 26 Oct. 1970.

80. In 1970, Ceaușescu decided to buy a nuclear power plant from the USSR, which did not function on heavy water. Gheorghe, 'Atomic Maverick', 390.

81. ANIC, CC PCR, Relații Externe, 98/1970, Report by Gheorghe Rădulescu to Nicolae Ceaușescu regarding the visit of the governmental delegation to the DRV and the PRC, 12 Dec. 1970, 25-6.

82. Ibid.

83. Croitor, Romania și conflictul soviet-chinez, 356, 359, 361; Munteanu, 'Communication Breakdown?', 627.

84. On Romania's relationship with the Soviet Union, see Eliza Gheorghe, 'Nicolae Ceausescu' in Steven Casey and Jonathan Wright (eds), Mental Maps in the Era of Détente and the End of the Cold War, 1968-1991 (London: Palgrave Macmillan, 2015), 67-72.

85. NARA, NPM, NSC Files Country Files - Europe, Rumania, vol. iii July 1970-Dec. 1971 to Rumania vol. iv Jan. 1972, box 703, Memorandum for the record. Visit of Romanian Ambassador Bogdan, 29 Dec. 1970.

86. Ibid.

87. NARA, NPM, NSC Files, Presidential/HAK MemCons, MemCon - Kissinger/Ambassador Bogdan 11 Jan. 1971 to MemCon - Kissinger at the Hoover Institute Board of Overseers' luncheon 17 Dec. 1971, box 1025, Memorandum for the President from Henry A. Kissinger regarding Conversation with Ambassador Bogdan, Map Room, 11 Jan. 1971.

88. In November 1970, there had been rumors circulating about an assassination attempt against Ceaușescu, which could have been seen as a Moscow-orchestrated plot. NARA, NPM, NSC Files Country Files - Europe, Rumania, vol. iii July 1970-Dec. 1971 to Rumania vol. iv Jan. 1972, box 703, Telegram from the US Embassy in Washington, DC, to the Secretary of State, Rumored Assassination Attempt Against Ceaușescu, 13 Nov. 1970.

89. NARA, RG 59, Subject Numeric Files, 1970-1973, Science, AE 6 to AE 10-2, box 2859, Airgram from the US Embassy in Bucharest to the Department of State, Renewal AEC/CNE Memorandum, 8 Jan. 1971; NARA, NPM, NSC Files, Presidential/HAK MemCons, MemCon - Kissinger/ Ambassador Bogdan 11 Jan. 1971 to MemCon - Kissinger at the Hoover Institute Board of Overseers' luncheon 17 Dec. 1971, box 1025, Memorandum for the President from Henry A. Kissinger regarding the Conversation with Ambassador Bogdan, Map Room, 11 Jan. 1971.

90. NARA, NPM, NSC Files, Presidential/HAK MemCons, MemCon - Kissinger/Ambassador Bogdan 11 Jan. 1971 to MemCon - Kissinger at the Hoover Institute Board of Overseers' luncheon 17 Dec. 1971, box 1025, Memorandum for the President from Henry A. Kissinger regarding the Conversation with Ambassador Bogdan, Map Room, 11 Jan. 1971.

91. NARA, NPM, NSC Files, Presidential/HAK MemCons, MemCon - Kissinger/Ambassador Bogdan 11 Jan. 1971 to MemCon - Kissinger at the Hoover Institute Board of Overseers' luncheon 17 Dec. 1971, box 1025, Memorandum of conversation between Ambassador Corneliu Bogdan, Henry A. Kissinger, David R. Halperin, 29 Jan. 1971.

92. NARA, NPM, NSC, Country Files - Europe, Rumania, vol. iii July 1970-Dec. 1971 to Rumania vol. iv Jan. 1972, box 703, Telegram from the US Embassy in Bucharest to William Rogers, South/ East Asia, 24 Feb. 1971.

93. ANIC, CC PCR, Relații Externe, 72/1969, Minutes of conversation between lon Gheorghe Maurer, Paul Niculescu Mizil and Zhou Enlai, 11 Sep. 1969, 43.

94. NARA, NPM, NSC, Country Files - Europe, Rumania, vol. iii July 1970-Dec. 1971 to Rumania vol. iv Jan. 1972, box 703, Telegram from the US Embassy in Bucharest to William Rogers, South/ East Asia, 24 Feb. 1971. 
95. AMAE, Telegrams from Beijing, vol. i, 1971, Telegram from Aurel Duma to Nicolae Ceaușescu, 23 March 1971, 56187, 291, in Romulus loan Budura, Politica independentă a României și relațiile româno-chineze: 1954-1975 (Bucharest: Arhivele Naționale ale României, 2008), 1057.

96. In the fall of 1970, Mao told Edgar Snow that he would be willing to hold talks with Nixon. The Americans failed to pick up this signal. MacMillan, Nixon and Mao, 174; Fedotov, Polveka vmeste s Kitaem, 376.

97. MacMillan, Nixon and Mao, 176-81.

98. Miller Center, University of Virginia, White House Tapes, President Nixon and Bob Haldeman discuss Donald Rumsfeld, 9 March 1971, Conversation no. 464-12, available at: https://miller center.org/the-presidency/educational-resources/nixon-and-bob-haldeman-on-donald-rums feld; ANIC, CC PCR, Relații Externe, 42/1971, Americans requesting the facilitation of contacts between the US and the PRC sent through the Ministry of Foreign Affairs, Sep. 1969-April 1971, 121, cited in Croitor, Romania și conflictul soviet-chinez, 359.

99. In 1973, Kissinger reiterated this proposal to establish a hotline to Zhou Enlai to which the Chinese never responded. William Burr (ed), The Kissinger Transcripts: The Top Secret Talks with Beijing and Moscow (New York: New Press, 1999), 203-4.

100. ANIC, CC PCR, Relații Externe Alfabetic, 8S/1969-1972, Letter from President Richard Nixon to President Nicolae Ceaușescu, 16 April 1971, 283.

101. ANIC, CC PCR, Relații Externe Alfabetic, 8S/1969-1972, Letter from Maurice Stans to President Nicolae Ceaușescu, 26 April 1971, 297.

102. NARA, NPM, NSC Files, For the President's Files - China/Vietnam Negotiations, China's memcons and memos - originals July 1971 to Bruce, Ambassador [memcons], box 1033, Memorandum from Winston Lord to Henry A. Kissinger, 4 June 1971.

103. On 27 April, the Pakistanis delivered a message which helped Washington and Beijing overcome the stalemate resulting from the February escalation in Laos. Beijing made an important concession that allowed the talks to move forward: the Chinese dropped the resolution of the Taiwan question as the pre-condition for the visit of a high-level US representative to China. MacMillan, Nixon and Mao, 181.

104. ANIC, CC PCR, Relații Externe, 40/1971, Minutes of conversation between Nicolae Ceaușescu and lon Gheorghe Maurer with Zhou Enlai, 3 June 1971, 61.

105. ANIC, CC PCR, Cancelarie, 72/1971, Protocol of the Permanent Presidium of the Central Committee of the Romanian Communist Party, 25 June 1971, 16.

106. AMAE, 212/1971 USA, Romanian-American Cooperation in the field of atomic energy, Telegram from lon Mînzatu to Virgil Constantinescu, 16 Nov. 1971, 28.

107. NARA, NPM, NSC Files, Presidential/HAK MemCons, MemCon - Kissinger/Ambassador Bogdan 11 Jan. 1971 to MemCon - Kissinger at the Hoover Institute Board of Overseers' luncheon 17 Dec. 1971, box 1025, Memorandum of conversation between Ambassador Corneliu Bogdan and Henry A. Kissinger, 31 Aug. 1971.

108. AMAE, 212/1971 USA, Romanian-American Cooperation in the field of atomic energy, 5.

109. ANIC, CC PCR, Relații Externe, 179/1971, Memorandum of conversation between Nicolae Ceaușescu and Glenn Seaborg, 20 Sep. 1971, 3.

110. Idem, 4.

111. Ibid.

112. Idem, 5 .

113. Ibid.

114. NARA, NPM, White House Central Files, Subject Files, Atomic Energy, box 1, Letter from Henry A. Kissinger to James R. Schlesinger, 4 Oct. 1971.

115. NARA, Access to Archives Database, Telegram from Henry Kissinger to the US Embassy in Ottawa, 3 Feb. 1976.

116. Francis J. Gavin, 'Nuclear Nixon: Ironies, Puzzles, and the Triumph of Realpolitik' in Fredrik Logevall and Andrew Preston (eds), Nixon in the World. American Foreign Relations, 1969-1977 (Oxford: Oxford University Press, 2008), 127. 


\section{Acknowledgments}

The author is grateful for comments and suggestions from Målfrid Braut-Hegghammer, Anne Deighton, Louise Fawcett, Adriana Gheorghe, John Harper, Fintan Hoey, David Holloway, Sven Holtsmark, Margaret MacMillan, Leopoldo Nuti, Christian Ostermann, the participants to the Nuclear Proliferation International History Project workshop in Rome, Italy (December 2015), and the anonymous reviewers. The research on which this article is based was financed by the Norwegian Institute for Defense Studies, the Graduate Scholarship at St Catherine's College, University of Oxford, the Rațiu Family Foundation Fellowship, the George L. Abernethy Predoctoral Fellowship at the School of Advanced International Studies - Johns Hopkins University, the Stanton Foundation, the Romanian Cultural Institute, the Belfer Center for Science and International Affairs and the International Security Studies program at Yale. 